\title{
Perbandingan Aktivitas Antioksidan Ekstrak Etanol dan Heksana dari Daun Gedi Merah (Abelmoschus manihot)
}

\author{
Juan A. W. Prawiraa*, Lidya I. Momuata, Vanda S. Kamua \\ aJurusan Kimia, FMIPA, Unsrat, Manado
}

K A T A K U N C I

Abelmoschus manihot

MDA

peroksida

\section{K E YW O R D S}

Abelmoschus manihot

MDA

Peroxide

\section{A B S T R A K}

Penelitian ini bertujuan untuk menentukan perbandingan aktivitas antioksidan ekstrak etanol dan heksana daun gedi merah dalam menghambat proses oksidasi lipida. Penelitian dimulai dengan mengekstraksi serbuk daun gedi merah yang sudah dikeringanginkan menggunakan cara maserasi selama 48 jam dengan pelarut etanol $75 \%$ dan pelarut heksana, selanjutnya ditentukan kandungan total fenolik serta aktivitas penghambatan oksidasi. Aktivitas penghambatan oksidasi diukur berdasarkan analisis kadar peroksida dan malondialdehida (MDA). Hasil penelitian menunjukkan bahwa ekstrak etanol memiliki kandungan total fenolik sebesar $28,68 \mathrm{mg} / \mathrm{kg}$ dan ekstrak n-heksana sebesar 2,86 $\mathrm{mg} / \mathrm{kg}$. Kemampuan penghambatan peroksida maupun MDA oleh ekstrak etanol lebih tinggi daripada ekstrak n-heksana.

A B S T R A C T

The purpose of this research is to compare the antioxidant activity of ethanol and hexane extract of leaves of red gedi in inhibiting lipid oxidation process. The research begins by extracting the red gedi leaf powder that has been dried using maceration for 48 hours with $75 \%$ ethanol and hexane solvent, then determined the total phenolic content and oxidation inhibition activity. Oxidation inhibition activity was measured by analysis of the levels of peroxide and malondialdehyde (MDA). The results showed that the ethanol extract has a total phenolic content of $28.68 \mathrm{mg} / \mathrm{kg}$ and $\mathrm{n}$-hexane extract at $2.86 \mathrm{mg} / \mathrm{kg}$. The ability MDA and peroxide inhibition by ethanol extract higher than $n$-hexane extract.

\section{Pendahuluan}

Dewasa ini terjadi peningkatan jumlah penderita penyakit degeneratif pada masyarakat dunia, seperti penyakit jantung koroner, hipertensi, stroke dan kanker. Peningkatan intensitas penyakit tersebut dapat disebabkan oleh beberapa faktor, di antaranya menurunnya kualitas lingkungan akibat pencemaran; pola makan yang cenderung memilih makanan siap saji yang berlemak dan berkolesterol tinggi; serta gaya hidup yang tidak sehat seperti merokok. Faktor-faktor ini memainkan peranan penting dalam pembentukan radikal bebas di dalam tubuh, yang secara keseluruhan disebut senyawa oksigen reaktif (SOR) yang dapat berupa molekul radikal hidroksil $\left(\mathrm{OH}^{\bullet}\right)$, radikal anion superoksida $\left(\mathrm{O}_{2}^{-\bullet}\right)$, radikal peroksil $(\mathrm{ROO} \cdot)$, hidrogen peroksida $\left(\mathrm{H}_{2} \mathrm{O}_{2}\right)$ dan oksigen singlet $\left({ }^{1} \mathrm{O}_{2}\right)$. SOR dan radikal bebas tersebut akan menyerang senyawa lipida tak-jenuh karena memiliki gugus yang kaya akan elektron. SOR tersebut akan bergabung dengan lipida sehingga akan menghasilkan peroksida lipida. Cara yang paling efektif untuk menetralisir efek radikal bebas adalah dengan pemberian antioksidan (Halliwel dan Gutteridge, 1991; Salonen, 1995).

Antioksidan adalah senyawa yang mampu memperlambat atau menangkal proses oksidasi, baik yang diakibatkan oleh radikal bebas maupun agen pengoksidasi lainnya. Secara alami, tubuh manusia memiliki antioksidan enzimatik, seperti superoksida dismutase (SOD), katalase, reduktase, dan glutation peroksidase yang berfungsi melindungi sel dari pengaruh toksik metabolik (Yen dan Hsieh, 2000). Tetapi antioksidan enzimatik ini tidak dapat menangkal semua agen pengoksidasi yang masuk ke dalam tubuh melalui udara ataupun makanan, sehingga dibutuhkan asupan tambahan antioksidan, yang secara alami dapat berasal dari buah-buahan, rempah-rempah dan sayur-sayuran. Salah satu contoh

*Corresponding author: Jurusan Kimia FMIPA UNSRAT, Jl. Kampus Unsrat, Manado, Indonesia 95115; Email address: jpyura@gmail.com

Published by FMIPA UNSRAT (2015) 
senyawa yang terkandung dalam tanaman dan terbukti mempunyai aktivitas antioksidan adalah senyawa fenolik.

Gedi merah (Abelmoschus manihot L.) merupakan salah satu jenis tanaman yang telah lama digunakan oleh masyarakat di Sulawesi Utara (Sulut) sebagai sayuran dan diyakini memiliki khasiat untuk menyembuhkan beberapa penyakit, seperti menurunkan kadar kolesterol plasma, menyembuhkan penyakit usus buntu dan melancarkan proses kelahiran bayi. Beberapa penelitian mengenai manfaat tanaman gedi merah dalam hubungannya dengan efek pengobatan telah dilaporkan. Gani et al. (2013) melaporkan bahwa daun gedi merah dapat menurunkan kadar kolesterol dari tikus yang mengalami hiperkolestrolimia; Jain et al. (2009) melaporkan bahwa ekstrak metanol dan ekstrak petroleum eter dari daun gedi merah memiliki efek antiinflamasi.

Sejauh ini, belum diperoleh informasi mengenai perbandingan ekstrak polar dan non-polar dari daun gedi merah dalam menangkal radikal bebas dan penghambatan oksidasi lipida. Sehingga diperlukan penelitian lebih lanjut untuk mengkaji kemampuan ekstrak tanaman gedi merah ini. Untuk itulah penelitian ini dilakukan, dengan memanfaatkan pelarut etanol untuk mendapatkan ekstrak etanol, serta pelarut heksana untuk ekstrak nonpolar. Lipida yang digunakan adalah minyak ikan hiu karena banyak mengandung asam lemak yang tak-jenuh sehingga lebih mudah mengalami reaksi oksidasi. Penelitian ini bertujuan untuk menentukan perbandingan aktivitas antioksidan ekstrak etanol dan heksana daun gedi merah dalam menghambat proses oksidasi lipida.

\section{Bahan dan Metode}

\subsection{Alat dan Bahan}

Alat yang digunakan dalam penelitian ini adalah alat-alat gelas pyrex, ayakan 60 mes, centrifuge, kertas saring, pipet, neraca analitik, oven, penggiling, pengaduk magnet, evaporator, spatula stainless stell, vorteks, dan spektrofotometer UV-Vis.

Bahan penelitian yang digunakan berupa daun Gedi Merah yang diperoleh dari kota Manado, minyak ikan hiu, carboxy methyl cellulose (CMC), $\alpha$-tokoferol, etanol 95\%, asam klorida, ammonium tiosianat, ferri klorida $\left(\mathrm{FeCl}_{2}\right)$, larutan bufer fosfat $\mathrm{pH} \mathrm{7,} \mathrm{asam}$ tiobarbiturat (TBA) dan asam trikloroasetat (TCA), heksana serta akuades.

\subsection{Persiapan dan Ekstraksi Sampel}

Sampel gedi merah dicuci dan dikeringanginkan selama 7 hari, kemudian digiling sampai halus lalu diayak dengan ayakan 60 mes. Sebanyak 100 g serbuk sampel gedi merah diekstraksi dengan cara direndam menggunakan etanol $80 \%$ selama 48 jam dalam suhu $5{ }^{\circ} \mathrm{C}$ dan selanjutnya disaring. Kemudian filtrat diuapkan dengan evaporator sehingga diperoleh ekstrak kental gedi merah, lalu ekstrak kental dipanaskan dalam oven dengan suhu $40^{\circ} \mathrm{C}$ selama 24 jam sehingga didapat ekstrak kering gedi merah. Proses ekstraksi yang sama diulangan dengan menggunakan pelarut heksana. Rendemen ekstrak yang diperoleh dihitung menggunakan rumus:

$$
\% \text { rendemen }=\frac{\text { berat ekstrak }(\mathrm{g})}{\text { berat serbuk }(\mathrm{g})} \times 100 \%
$$

\subsection{Penentuan Kandungan Total Fenolik (Conde et al., 1997)}

Sebanyak 0,1 mL larutan ekstrak $1 \mathrm{mg} / \mathrm{mL}$ dalam etanol ditambahkan $0,1 \mathrm{~mL}$ reagen FolinCiocalteau 50\%. Kemudian divorteks selama 3 menit dan ditambahkan $2 \mathrm{~mL}$ larutan $\mathrm{Na}_{2} \mathrm{CO}_{3} 2 \%$ lalu divorteks kembali. Selanjutnya campuran diinkubasi selama 30 menit pada suhu ruang, dan dibaca absorbansinya pada spektrofotometer UV-Vis dengan panjang gelombang $750 \mathrm{~nm}$. Kandungan total fenolik dinyatakan sebagai $\mathrm{mg}$ ekivalen asam galat/kg ekstrak.

\subsection{Analisis Kadar Peroksida pada Minyak Ikan}

Sebanyak $2 \mathrm{~mL}$ minyak ikan 10\% dalam etanol 96\% ditambahkan $2 \mathrm{~mL}$ carboxy methyl cellulose $0,5 \%$ sebagai penstabil emulsi. Selanjutnya, campuran ditambahkan $4 \mathrm{~mL}$ buffer fosfat $0,1 \mathrm{M}(\mathrm{pH}$ 7) dan $2 \mathrm{~mL}$ akuades dan disimpan dalam wadah gelap tertutup. Campuran tersebut diinkubasi pada suhu sekitar $37-40{ }^{\circ} \mathrm{C}$, dan dijadikan sebagai blanko.

Analisis kadar peroksida dari minyak ikan (blanko) dilakukan 2 hari sekali dengan metode ferri tiosianat, yaitu $100 \mu \mathrm{L}$ campuran ditambahkan dengan 2,35 $\mathrm{mL}$ etanol $75 \%$ dan $50 \mu \mathrm{L}$ ammonium tiosianat 30\%. Setelah ditambahkan $50 \mu \mathrm{L} \mathrm{FeCl}_{2}$ 0,02 $\mathrm{M}$ dalam 3,5\% larutan $\mathrm{HCl}$, campuran didiamkan selama 3 menit. Absorbansi blanko diukur pada panjang gelombang $500 \mathrm{~nm}$. Berdasarkan pengukuran absorbansi peroksida blanko tersebut dapat ditentukan waktu inkubasi untuk mencapai absorbansi maksimum (hari ke-x) (Chen et al., 1996).

Pengerjaan yang sama dilakukan juga untuk ekstrak sampel gedi merah dan $\alpha$-tokoferol (kontrol), dengan mengganti akuades pada blanko dengan ekstrak sampel dan $\alpha$-tokoferol. Untuk analisis kadar peroksida, konsentrasi masing-masing ekstrak sampel dan $\alpha$-tokoferol dibuat $100 \mu \mathrm{g} / \mathrm{mL}$ dan 200 $\mu g / m L$.

\subsection{Analisis Kadar Malondialdehida (MDA) pada Minyak Ikan}

Setelah diperoleh waktu inkubasi untuk mencapai absorbansi maksimum (hari ke-x), dilakukan pengukuran MDA pada blanko, kontrol, dan ekstrak gedi merah (etanol dan heksana). Sebanyak $2 \mathrm{~mL}$ campuran yang telah diinkubasi selama $\mathrm{x}+2$ hari, ditambahkan $2 \mathrm{~mL}$ larutan TCA 20\% dan $2 \mathrm{~mL}$ larutan TBA $1 \%$ dalam pelarut asam asetat $50 \%$. Lalu campuran ditempatkan pada penangas air mendidih selama 10 menit. Setelah didinginkan, disentrifugasi pada kecepatan $3000 \mathrm{rpm}$ selama 20 menit. Absorbansi supernatan diukur pada panjang gelombang 532 nm (Kikuzaki dan Nakatani, 1993). 
Hal yang sama dilakukan juga pada campuran yang mengandung ekstrak gedi merah dan $\alpha$-tokoferol.

Persen penghambatan MDA dihitung dengan rumus:

$\%$ penghambatan $=100 \%-\left(\frac{\text { abs. sampel }}{\text { abs. blanko }} \times 100 \%\right)$

\section{Hasil dan Pembahasan}

\subsection{Ekstraksi}

Rendemen ekstrak yang didapat dari proses ekstraksi dengan metode maserasi serbuk daun gedi merah dengan menggunakan pelarut etanol $75 \%$ dan heksana dapat dilihat pada Tabel 1.

Tabel 1 - Rendemen ekstrak hasil ekstraksi

\begin{tabular}{|l|c|c|c|}
\hline \multirow{2}{*}{ Sampel } & \multicolumn{2}{|c|}{ Massa (g) } & Rendemen \\
\cline { 2 - 3 } & Serbuk & Ekstrak Kental & \\
\hline $\begin{array}{l}\text { Etanol } \\
80 \%\end{array}$ & 100 & 4,72 & 4,72 \\
\hline Heksana & 100 & 2,27 & 2,27 \\
\hline
\end{tabular}

Nilai dari rendemen yang diperoleh menunjukkan banyaknya komponen yang dapat diekstrak dari suatu sampel oleh pelarut. Pada Tabel 1 dapat dilinat bahwa total rendemen ekstrak etanol $(4,72 \%)$ lebih besar daripada ekstrak heksana (2,27\%). Hal ini menunjukkan bahwa daun gedi merah memiliki lebih banyak komponen polar daripada komponen nonpolarnya.

\subsection{Kandungan Total Fenolik}

Pengukuran kandungan total fenolik dapat diukur menggunakan reagen Folin-Ciocalteu. Reagen FiolinCiocalteu dapat bereaksi dengan senyawa fenolik dan akan menghasilkan suatu kompleks $\mathrm{Mo}^{5+}$ yang berwarna biru dan dapat diukur dengan spektrofotometer pada panjang gelombang $750 \mathrm{~nm}$. Campuran yang memiliki warna biru yang lebih pekat menunjukkan nilai absorbansi yang lebih besar. Semakin besar nilai absorbansi yang terbaca pada spektrofotometer, maka semakin tinggi kandungan fenolik pada ekstrak tersebut. Hasil pengukuran kandungan total fenolik ekstrak gedi merah dari ekstrak etanol $(\mathrm{E})$ dan heksana $(\mathrm{H})$ dapat dilihat pada Gambar 1.

Gambar 1 menunjukkan bahwa kandungan total fenolik dari ekstrak gedi merah untuk ekstrak etanol $28,98 \mathrm{mg} / \mathrm{kg}$ dan untuk ekstrak heksana $2,86 \mathrm{mg} / \mathrm{kg}$. Ekstrak etanol memiliki total kandungan fenolik 10 kali lebih tinggi dibandingkan ekstrak heksana. Hal ini menunjukkan senyawa fenolik lebih larut dalam pelarut polar dibandingkan dengan pelarut nonpolar, disebabkan karena adanya gugus-gugus hidroksil ($\mathrm{OH})$ pada senyawa fenolik yang bersifat polar.

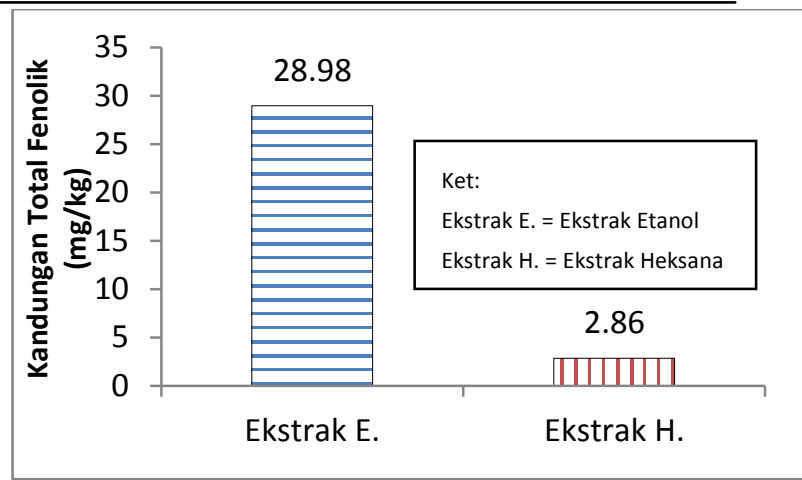

Gambar 1 - Kandungan total fenolik pada ekstrak gedi merah

Namun, kandungan total fenolik pada penelitian ini lebih rendah dibanding penelitian sebelumnya yang dilakukan oleh Suoth et al. (2013) yaitu sebesar 1003,5. Ini disebabkan karena perbedaan pada jenis pelarut dan proses ekstraksi. Proses ekstraksi yang digunakan dalam penelitian ini menggunakan metode maserasi dalam suhu $5{ }^{\circ} \mathrm{C}$ yang mengakibatkan senyawa fenolik sukar larut ke dalam pelarut karena senyawa fenolik sukar larut dalam suhu yang rendah.

\subsection{Kadar Bilangan Peroksida pada Minyak Ikan}

Gambar 2 menunjukkan nilai absorbansi peroksida blanko selama 12 hari inkubasi. Perhitungan berkala nilai peroksida blanko menunjukkan absorbansi maksimum. Nilai absorbansi maksimum merupakan indikator telah teroksidasinya minyak ikan menjadi senyawa peroksida, sebelum malonaldehida (MDA) terbentuk. MDA terbentuk dari dekomposisi senyawa peroksida. Nilai absorbansi blanko mencapai nilai maksimum pada hari ke-10, sehingga pada pengujian MDA dilaksanakan setelah hari ke-10.

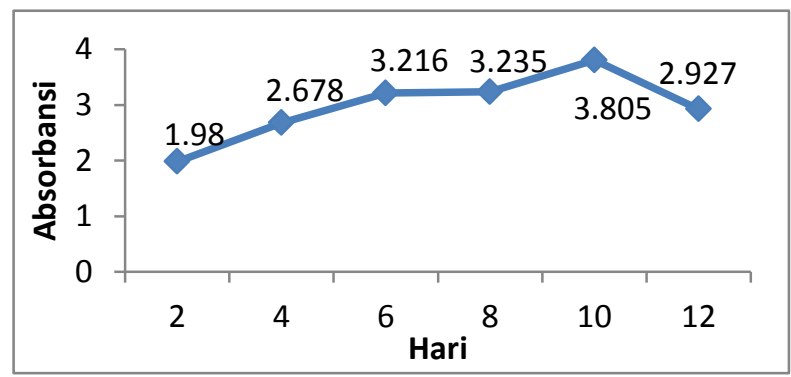

Gambar 2 - Absorbansi peroksida blanko selama $x$ hari

Berdasarkan data pengukuran absorbansi blanko dapat dihitung besar penghambatan peroksida pada saat nilai absorbansi maksimum, untuk campuran yang mengandung ekstrak etanol dan heksana daun gedi merah, serta $\alpha$-tokoferol. Hasil dari perhitungan besar penghambatan peroksida dari ekstrak etanol $(E)$, ekstrak heksana $(H)$ dan $\alpha$-tokoferol tertera pada Gambar 3. 


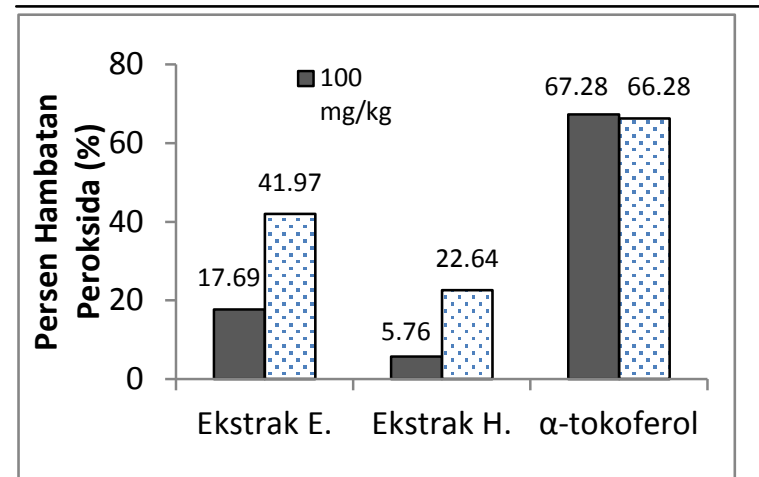

Gambar 3 - Besar persen hambatan setiap substrat

Pada Gambar 3, jika dibandingkan antara ekstrak aktivitas penghambatan peroksida yang paling tinggi adalah ekstrak etanol yaitu sebesar 41,97\% untuk konsentrasi $200 \mathrm{mg} / \mathrm{kg}$ dan 17,69\% untuk konsentrasi $100 \mathrm{mg} / \mathrm{kg}$, Sedangkan ekstrak heksana memiliki kemampuan menghambat yang lebih rendah yaitu sebesar 22,64\% untuk konsentrasi $200 \mathrm{mg} / \mathrm{kg}$ dan 5,76\% untuk konsentrasi $100 \mathrm{mg} / \mathrm{kg}$. Hal ini menunjukkan bahwa ekstrak etanol memiliki kemampuan menghambat oksidasi lebih baik dibandingkan dengan ekstrak heksana.

\subsection{Kadar Malondialdehida pada Minyak Ikan}

Pengukuran senyawa malondialdehida (MDA) dalam suatu sistem dapat menjadi tolak ukur untuk aktivitas antioksidan. Senyawa antioksidan dapat menghambat pembentukan senyawa MDA.

Pada penelitian ini, banyaknya senyawa MDA dalam campuran minyak ikan ditunjukkan dengan besarnya nilai absorbansi. Semakin rendah nilai absorbansi MDA menunjukkan semakin efektifnya ekstrak dalam menghambat pembentukan senyawa malondialdehida. Gambar 4 menyajikan besarnya persen penghambatan pembentukan MDA dari ekstrak etanol $(E)$, heksana $(H)$ dan $\alpha$-tokoferol pada minyak ikan yang telah diinkubasi selama 12 hari.

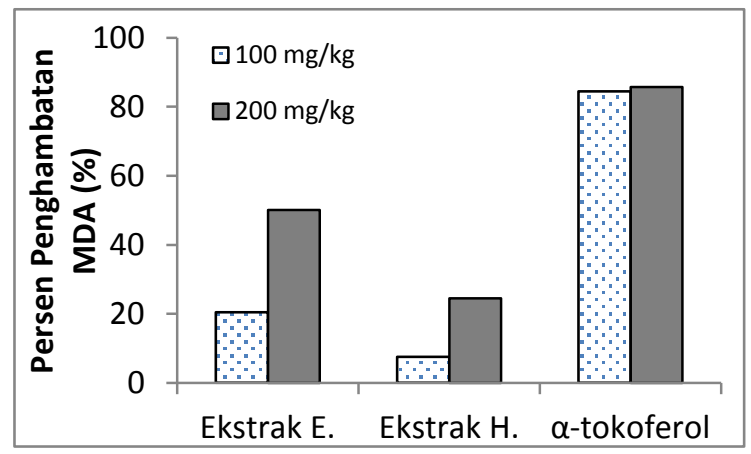

Gambar 4 - Persen hambatan pembentukan MDA

Pada Gambar 4 dapat dilihat bahwa ekstrak yang paling baik menghambat pembentukan MDA adalah ekstrak etanol $200 \mathrm{mg} / \mathrm{ml}$, diikuti dengan ekstrak heksana $200 \mathrm{mg} / \mathrm{ml}$, ekstrak etanol $100 \mathrm{mg} / \mathrm{ml}$ dan ekstrak heksana $100 \mathrm{mg} / \mathrm{ml}$, masing-masing ekstrak memiliki besar penghambatan sebagai berikut:
50,16\%; 24,56\%; 20,38\%; 7,47\%. Hal ini sejalan dengan nilai kandungan total fenolik yang diuji, campuran etanol $200 \mathrm{mg} / \mathrm{ml}$ memiliki nilai yang lebih tinggi dibandingkan dengan campuran heksana 200 $\mathrm{mg} / \mathrm{ml}$.

Namun, ekstrak etanol 200 mg/ml lebih rendah dibandingkan dengan kontrol postif yaitu $\alpha$-tokoferol yang memiliki persen penghambatan sebesar $85,79 \%$ untuk konsentrasi $200 \mathrm{mg} / \mathrm{kg}$ dan 84,40\% untuk konsentrasi $100 \mathrm{mg} / \mathrm{kg}$ disebabkan karena kurang efektifnya proses ekstraksi sehingga senyawa yang berpotensi menjadi antioksidan tidak ikut terekstraksi.

\section{Kesimpulan}

Dari hasil penelitian ini dapat disimpulkan sebagai berikut: Ekstrak etanol memiliki kandungan total fenolik yang lebih besar dibandingkan dengan ekstrak heksana dan ekstrak etanol $200 \mathrm{mg} / \mathrm{ml}$ memiliki kemampuan menghambat proses oksidasi yang lebih baik dibandingkan dengan ekstrak-ekstrak yang lainnya. Namun, ekstrak etanol memiliki kemampuan menghambat proses oksidasi yang lebih rendah dibandingkan dengan $\alpha$-tokoferol.

\section{Daftar Pustaka}

Chen, H.M., K. Muramoto, F. Yamauchi, and K. Nokihara. 1996. Antioxidant Activity of Designe Peptides Based on the Antioxidative Peptide Isolated from Digests of Soybean Protein. J. Agric. Food Chem. 44: 2619-2623.

Conde, E.F., M.C.Cadahia, Garcia-Vallejo, B.F.D. Simon, dan J.R.G. Adrados. 1997. Low Molecular Weight Polyphenol in Cork of Quercus Suber. J. Agric. Food Chem. 45: 2695-2700.

Gani, N., L. I. Momuat, dan M. Pitoi. 2013. Profil Lipida Plasma Tikus Wistar yang Hiperkolesterolemia pada Pemberian Gedi Merah (Abelmoschus manihot L.). J. Mipa Unsrat OI. 2: 44-49

Halliwel, B., and J.M.C. Gutteridge. 1991. Free Radicals in Biology and Medicine $2^{\text {th }}$ edition. Oxford University Press, New York.

Jain P.S. and S.B. Bari.2009. Isolation of Stigmasterol and $\mathrm{y}$-Sitosterol from Petroleum Ether Extract of Woody Stem of Abelmoschus manihot. Asian J Biol Sci. 2: 112-117.

Kikuzaki, H., and Nakatani, N. 1993. Antioxidant Effects of Some Ginger Constituents. J. Food Sci. 58: 1407-1410.

Salonen, J.T. 1995. The Role of Lipid Peroxidation and Natural Antioxidants in Cardiovascular Diseases. Dalam Kumpulainen, J.T., and J.T. Salonen (Eds). Natural Antioxidants and Food Quality in Atherosclerosis and Cancer Prevention. The Royal Society of Chemistry, Cambridge.

Suoth, E., H. Kaempe, dan A. Tampi. 2013.Evaluasi Kandungan Total Polifenol Dan Isolasi Senyawa 
JURNAL MIPA UNSRAT ONLINE 4 (1) 5-9

Flavonoid Pada Daun Gedi Merah (Abelmoschus Manihot L.). Chem. Prog. 6: 86-91.

(Eucommia ulmoides Oliv.) and Its Active Compound. J. Agric. Food Chem. 48: 3431-3435

Yen, G.H. and C.L. Hsieh. 2000. Reactive Oxygen Species Scavenging Activity of Du-zhong 